\title{
Plant oil derivates as fuels
}

\author{
Ferenc Farkas \\ Szolnok College Technical and Agricultural Faculty, Mechanical Department, PhD Ferenc Farkas
}

\begin{abstract}
The dependence of the Hungarian economy on energy imports has already reached that degree, which is forecast in the EU for the average of the community by 2020 .

The total quantity of the biomass in Hungary is $350-360$ mtons, out of which $105-110$ mtons reproduces itself annualy. The energy content of the yearly produced biomass is as high as $1185 \mathrm{PJ}$, which is $5 \%$ more than the annual energy consumption. The renewable energies which are produced by agriculture could cover $10 \%$ of the energy demand of Hungary for a short term.

At our College Faculty in Mezőtúr we have been dealing with the application issues of vegetable oil derivates as fuels since 1990 .
\end{abstract}

Keywords: renewable energies, climate protection, dependence on energy imports, Kyoto targets, biofuels.

\section{INTRODUCTION}

As a preliminary, I would like to cite a statement born in 1912: „Utilisation of vegetable oil as fuel is still insignificant today. In time these products will be as important as petrol and tar products are". This citation comes from Rudolf Diesel, which means that the idea of the bio-fuels is as old as of the engine itself. Nine years later the legendary tractor Lanz-Bulldog was presented in Mannheim, which can be understood as the first vegetable oil tractor as well. Thanks to its heater solution it was also absolutely suitable to use vegetable oil fuel. This „omnivorous” engine enjoyed quite great popularity till the end of $1950 \mathrm{~s}^{3}$.

The total quantity of the biomass in Hungary is $350-$ 360 mtons, out of which 105 - 110 mtons reproduces itself annually. The energy content of the yearly produced biomass is as high as $1185 \mathrm{PJ}$, which is $5 \%$ more than the annual energy consumption. The biggest biomass producer is agriculture, which produces 58 mtons a year. The quantity of biomass used for energetic purposes is only 1,8 mtons. The renewable energies, produced by agriculture could cover $10 \%$ of the energy demand of Hungary for a short term².

The main objectives of European climate protection were applied in the Hungarian environmental laws. The national quotas were allocated first in 2005, but the new allocation plan has not been submitted to the EU. It was easy for Hungary to fulfil the Kyoto targets, as at present the emission is significantly lower, than it was in 1990.

The EU energy policy focuses on the promotion of renewable energy sources. The EU encourages the extension of renewable fuels in transport.

The Parliament resolution aimed at alternative energy says that biofuel will have to reach $4 \%$ of the total fuel use by 2010 . In order to achieve its goals, Hungary has already started certain investments. In 2005 renewable energy accounted for $4,6 \%$ of the total use of energy.

The dependence of the Hungarian economy on energy imports has already reached that degree, which is forecast in the EU for the average of the Community by 2020. In

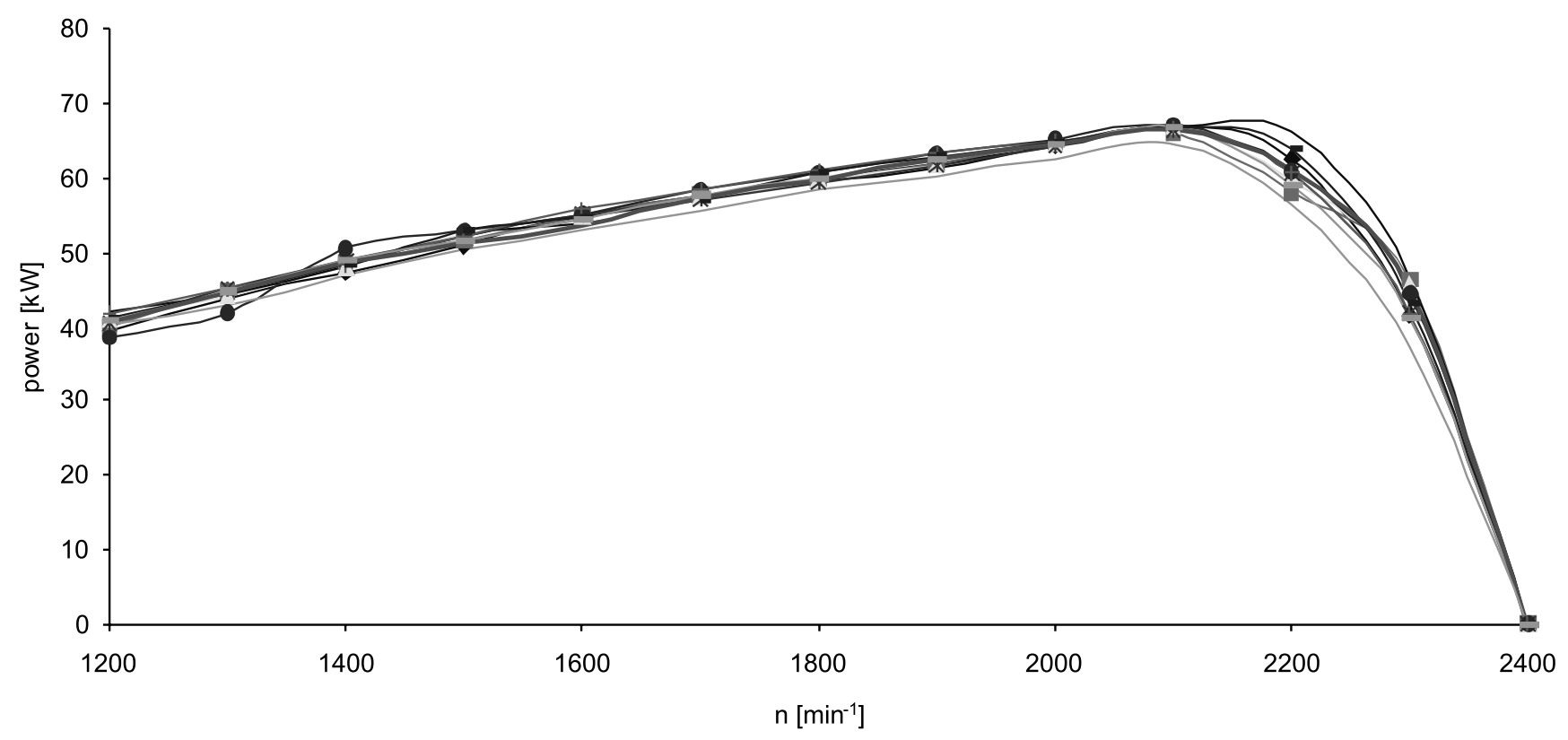

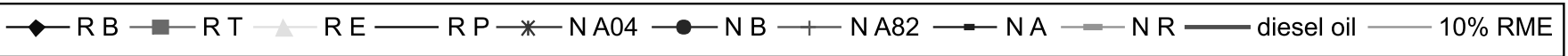

Figure 1. Power values with several fuels 


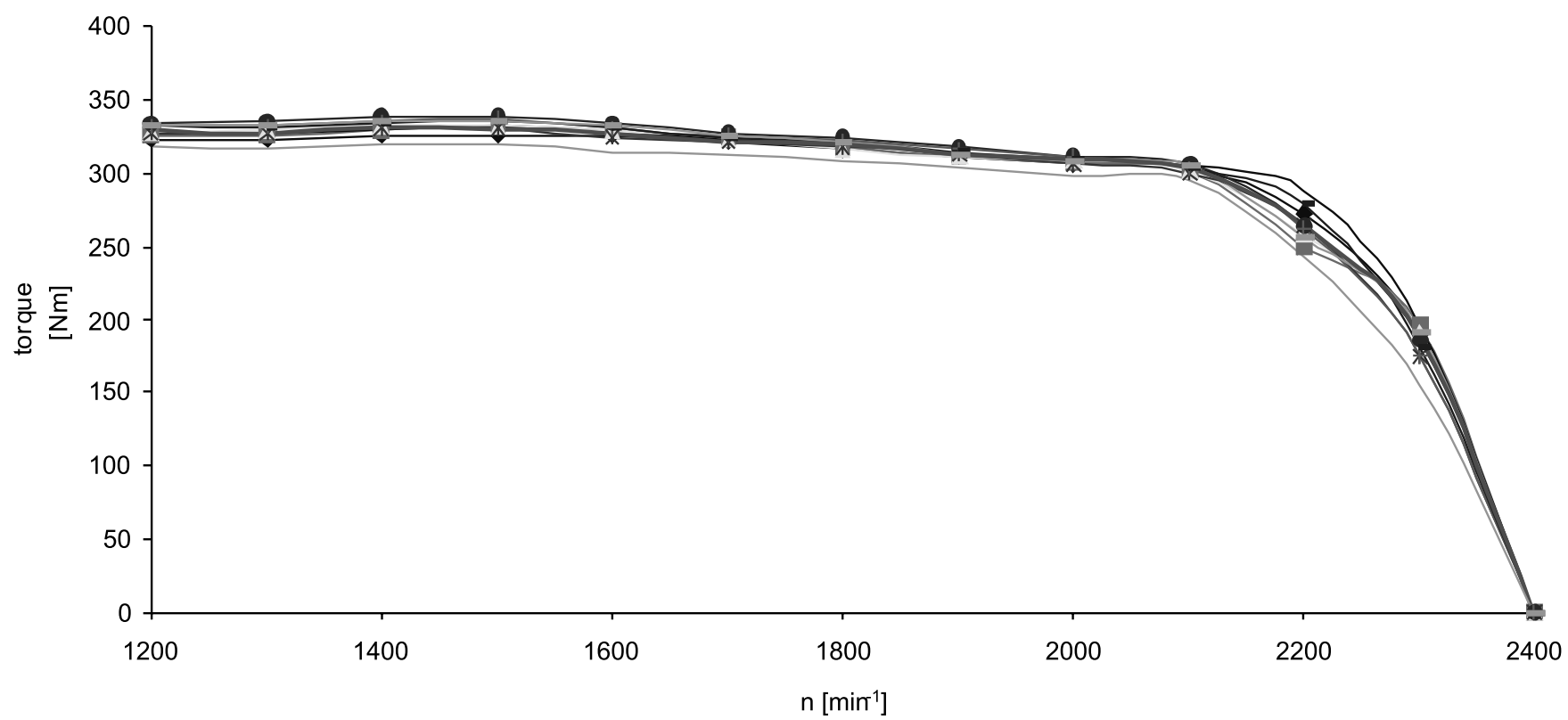

$-\mathrm{RB} \longrightarrow \mathrm{RT}-\mathrm{RE} \longrightarrow \mathrm{RP}$ - $-\mathrm{NA04}$

N A82

$\mathrm{NA}=-\mathrm{NR}=$ diesel oil

$10 \% \mathrm{RME}$

Figure 2. Torque values with several fuels

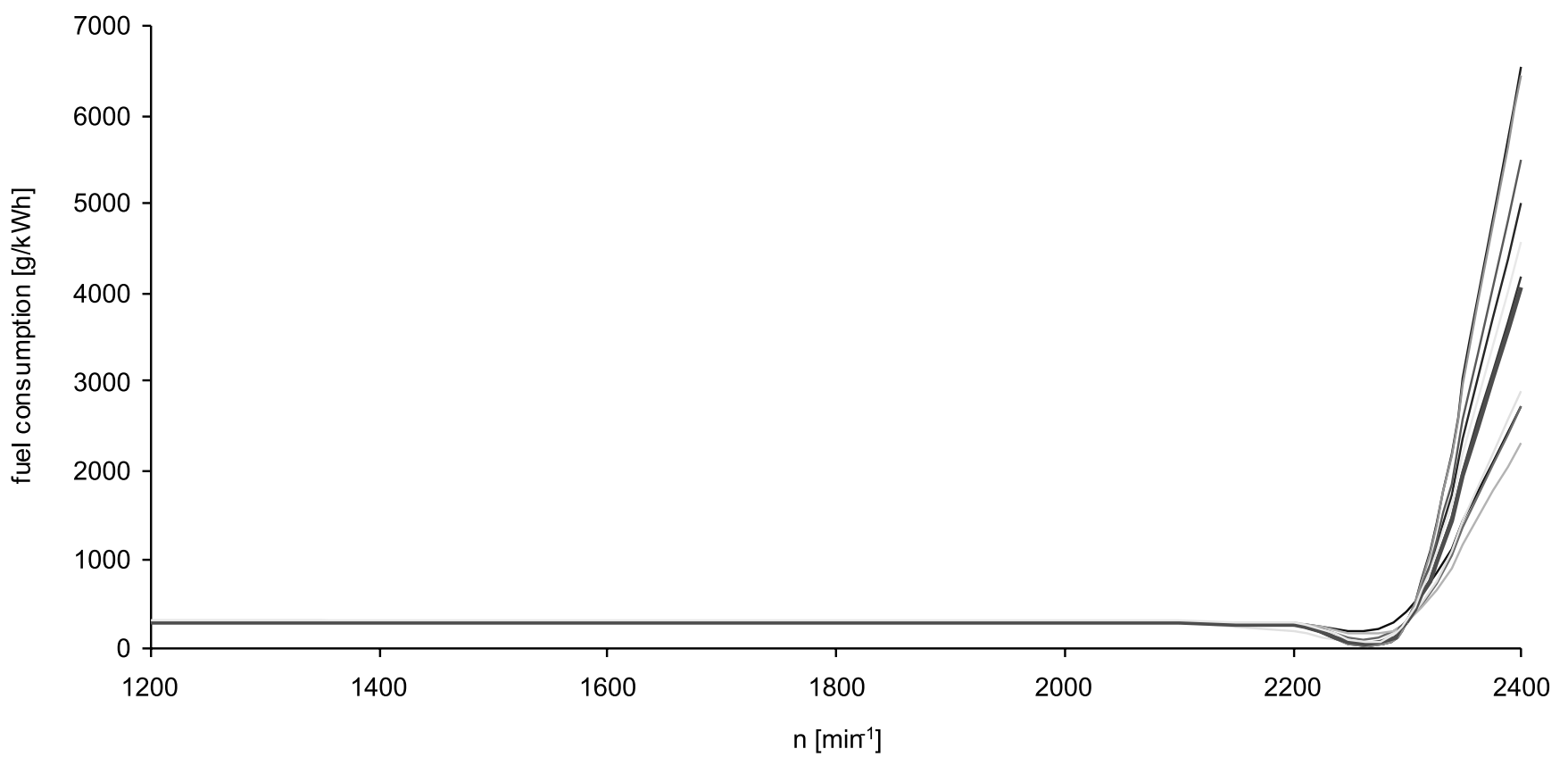

$\mathrm{R} B$

$\mathrm{RE}=\mathrm{RP}=\mathrm{NA04}$

$\mathrm{NB}-\mathrm{NA} 82$

NA $-\mathrm{NR} \longrightarrow$ diesel oil

$10 \%$ RME

Figure 3. Fuel consumption values with several fuels

addition, Hungary's energy supply relies almost entirely on Russian sources. There is a significant difference between the EU and Hungary, which means that Hungary's endowment with fossil energy is not only much below the EU average, but its renewable reserves are much less than those of the EU as well. In Hungary the renewable energy sources will play a much more modest role in substituting conventional energy sources and meeting a growing energy demand than in the $\mathrm{EU}^{\mathbf{1}, \mathbf{4}}$.

\section{METHOD OF RESEARCH WORK}

Nowadays I determined the engine brake bench results and the emission components using 5 kinds of the pressed sunflower oils mixed with diesel oil, 4 kinds of rape oils mixed with diesel oil and RME. My tests were performed while meeting the requirements of the EU 24 and EU 49 standards with PERKINS 1104C engine type at our College Faculty. In the course of my tests I put down $\mathrm{CO}, \mathrm{HC}$, $\mathrm{NO}_{\mathrm{x}}, \mathrm{CO}_{2}$ and $\mathrm{O}_{2}$ components of exhaust gases and determined smoking, too. 


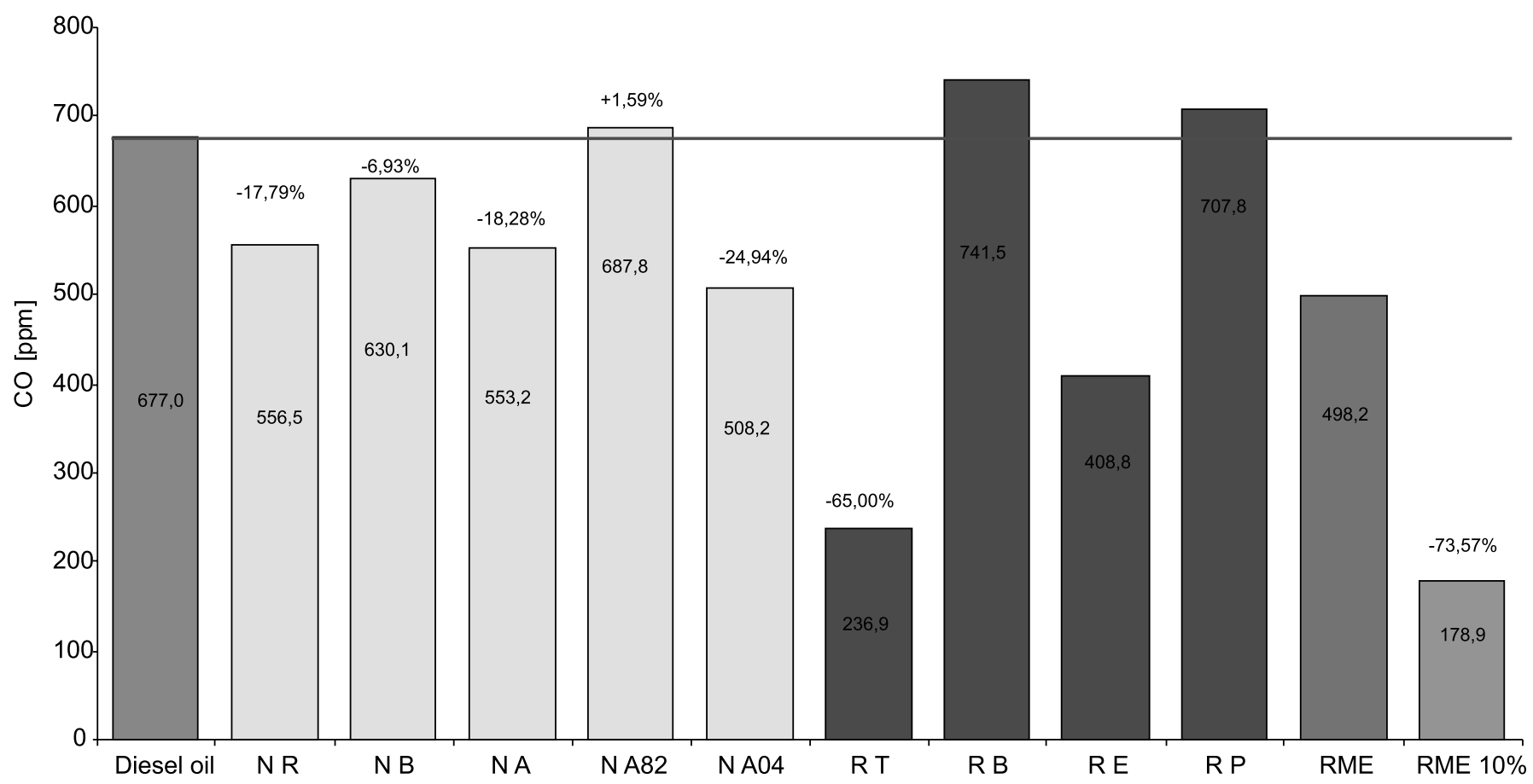

Figure 4. $\mathrm{CO}$ emission values

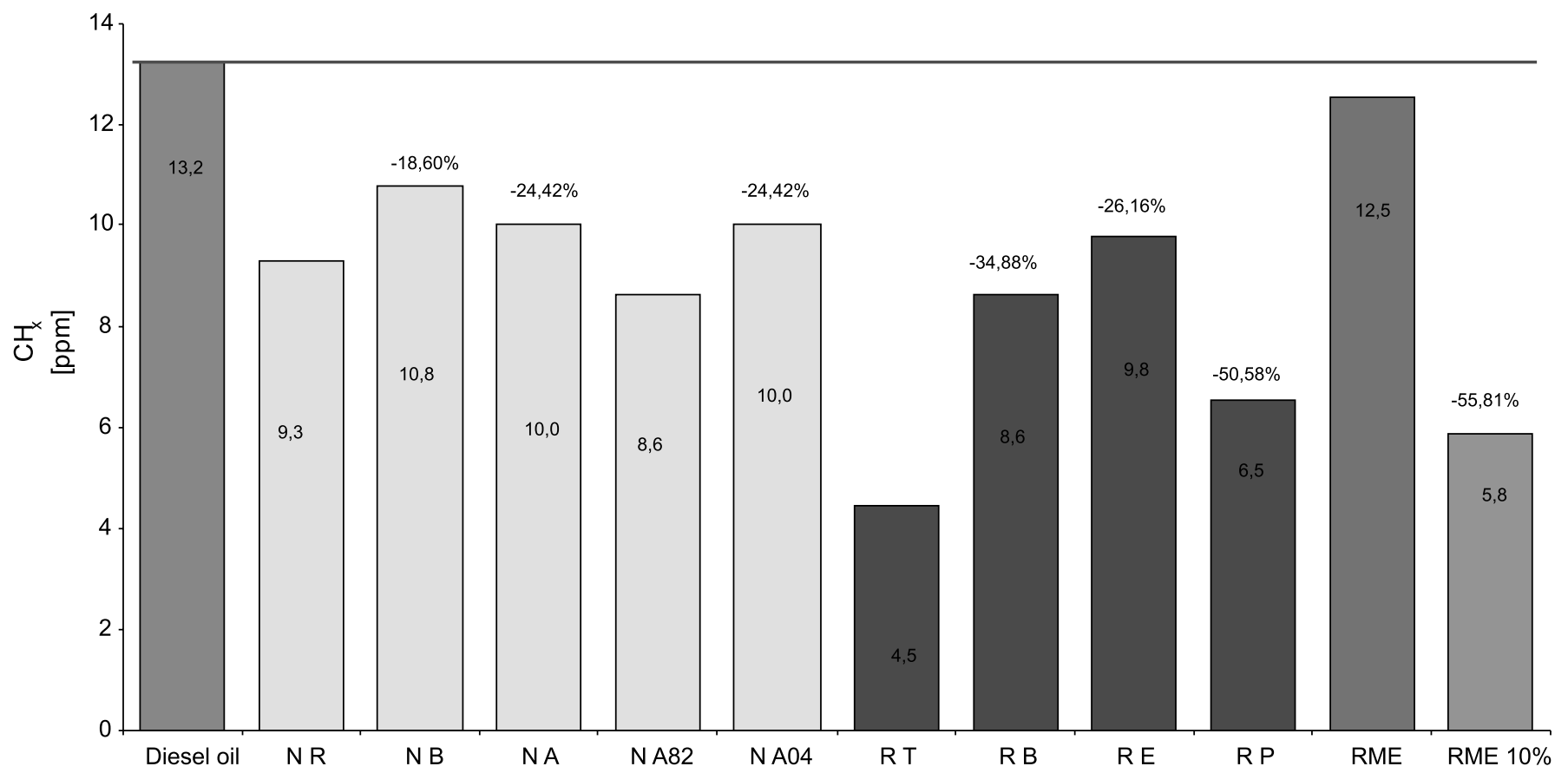

Figure 5. $\mathrm{CH}$ emission values

At our College Faculty in Mezőtúr we have been dealing with the application issues of vegetable oil derivatives as fuels since 1990 in the frame of discipline research supported by OTKA, PFP and NkFP.

\section{RESULTS OF TESTS CARRIED OUT}

On the engine brake bench tests all 10 working points were registered between 1100 1/min - 2400 1/min engine revolution with full load for every fuel.

We determined the average engine output for all kinds of vegetable oils (Figure 1). The values remained within $\pm 1 \%$, only the power of the $10 \%$ RME mixed fuel decreased by $4 \%$ from diesel oil.
We can report similar results about the torques of all the vegetable oil samples (Figure 2).

The fuel consumption of the four rape oils - diesel oil mixed fuels showed lower values between $14,76 \%$ and $22,37 \%$ compared with diesel oil, but the consumption of all the five sunflower oils - diesel oil mixed fuels exceeded the diesel oil rate with 1,59\% - 32,42\% (Figure 3).

After the emission tests it was stated that among the 5 kinds of sunflower oil mixed with diesel oil 4 fuels fell behind with $6,93 \%-24,94 \%$ from the $\mathrm{CO}$ value of diesel oil (Figure 4).

Among 4 kinds of rape oil mixed with diesel oil I noticed substantial falling (65\% and $39,61 \%)$ in two cases and rising $(9,52 \%$ and $4,56 \%$ twice $)$. The pure RME 


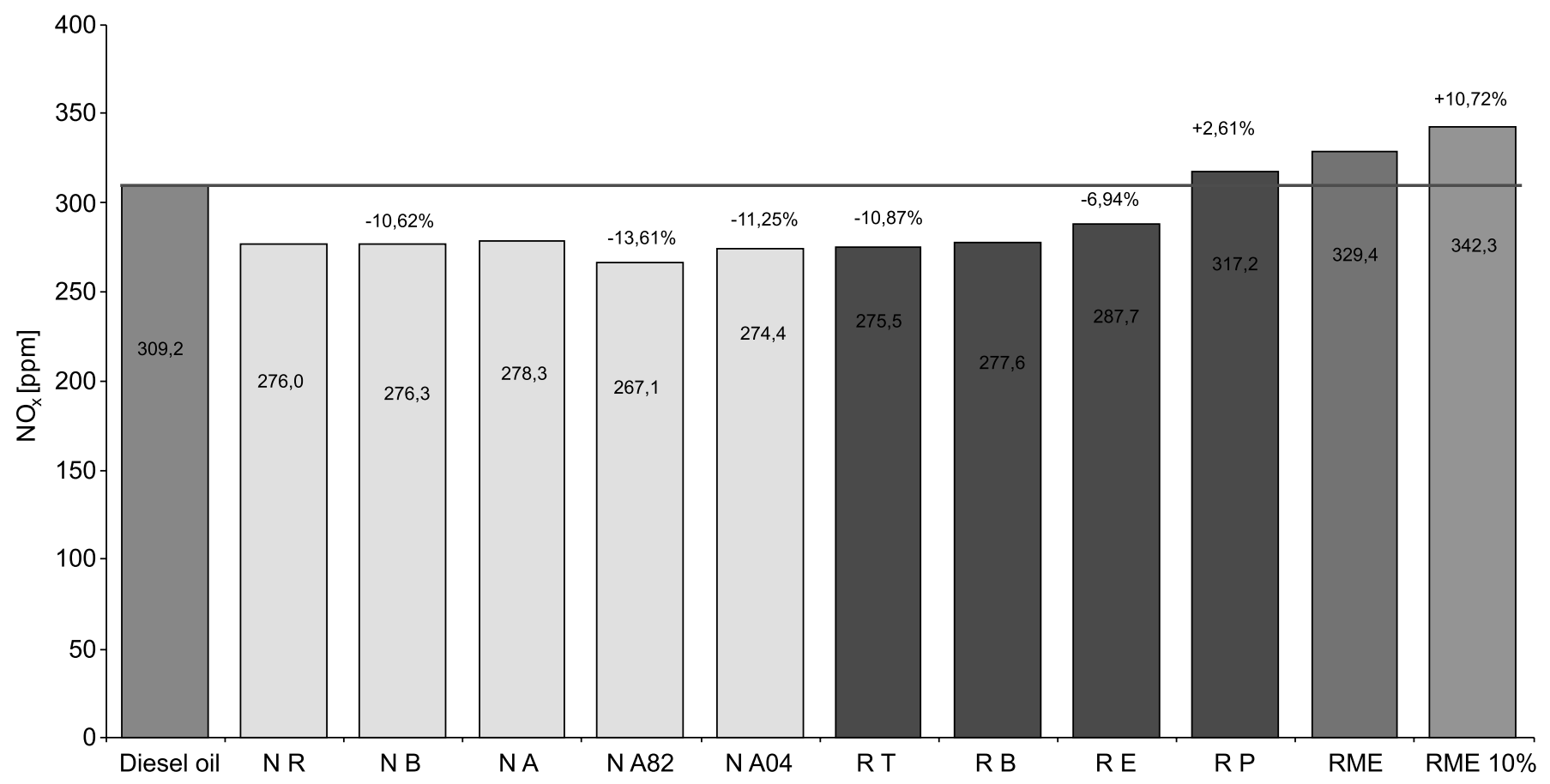

Figure 6. $\mathrm{NO}_{\mathrm{x}}$ emission values

showed 26,42\% less CO emission, the mixed fuel containing $10 \%$ RME decreased by $73,57 \%$.

$\mathrm{CH}$ emissions of all the vegetable oil-diesel oil mixed fuels remained below $\mathrm{CH}$ values of diesel oil (Figure 5).

For comparison, the values of the mixed fuels with sunflower oils to diesel oil dropped by $18,6 \%-34,88 \%$ and also slid by $26,16 \%-66,28 \%$ using the mixed fuels with rape oils. The pure RME represented 5,23\% less $\mathrm{CH}$ values, the mixed fuel containing $10 \% \mathrm{RME}$ dropped by $55,81 \%$.

Among the 10 kinds of vegetable oil-diesel oil mixed fuels I measured higher $\mathrm{NO}_{\mathrm{x}}$ values than in diesel oil in only two cases of mixed fuels (Figure 6).

The samples with sunflower oils were slightly more favourable than rape oil samples. Nine samples remained below the diesel fuel by $6,94 \%-13,61 \%$.

My further remark is that the values of pure RME exceeded the $\mathrm{NO}_{\mathrm{x}}$ limit of diesel oil with $6,54 \%$ and the mixed fuel containing $10 \%$ RME also exceeded by $10,72 \%$.

\section{CONCLUSIONS}

Keeping with the findings in literature, it can be stated unambiguously that the 10 types of vegetable oil derivates tested by me are suitable for use as diesel engine fuels.

The power and torque of vegetable oil mixed fuels showed lower values, than diesel oil, which can be explained with the less caloric values of vegetable oils. Sometimes we registered higher values, compared with diesel oil, a possible cause of which may be the higher viscosity. The bigger viscosity has an effect of full load. The total effects of rape oil mixed fuels were more favourable, than those of diesel fuels because of their different cetane numbers.

\section{LITERATURE CITED}

1. Barta , J. \& Hegedűs, M. A magyar energiapolitika az EU energiapolitikájának tükrében. GKI Kft., 2007, 3 - 4.

2. Hajdú , J. \& Magó, L. Az energiatermelő mezőgazdaság. Mezőgazdasági Technika, 8/2006, 2 - 4.

3. Neményi, M., Kacz, K. \& Stépán, Zs. RME mint motorhajtóanyag: a felhasználás gyakorlati tapasztalatai. Növényvédelmi tanácsok, 8/2000, 12 - 13.

4. Hancsók, J. \& Krár, M. Diesel-motorok újgenerációs bio-motorhajtóanyagai. „Conference of chemical Engineering”, Veszprém 2008, 7 - 12. 